\title{
The Influence of Explicit Cross-Linguistic Consciousness- Raising on the EL Writing of the Iranian English Language Learners
}

\author{
Seyyed Yavar Hosseininik \\ E-mail: yavar.141@gmail.com \\ Hamid Rahmani Sangani \\ Velayat University of Iranshahr, Iran \\ E-mail: H_Rahmani_s@yahoo.com
}

Doi:10.7575/aiac.alls.v.5n.3p. 147

URL: http://dx.doi.org/10.7575/aiac.alls.v.5n.3p.147
Received: 11/04/2014

Accepted: 18/05/2014

\begin{abstract}
This study investigates the effects of cross-linguistic consciousness-raising through comparing and contrasting learners'L1 (Persian) and L2 (English) on their L2 written performance. To do this, sixty intermediate language learners, both male and female, learning English at two private institutes in Yasuj, Iran, were chosen as the participants of the study. They were assigned to four groups, two experimental groups and two control groups. Two language items, i.e. subject-verb agreement and adverb position in a sentence were chosen as the materials to be taught in the study. At first, Three kinds of tests, i.e. recognition test, translation test and writing production test checking the participants' recognition of errors, proper use and correct production of the chosen language items respectively, were administered as the pre-tests. Afterwards, the experimental groups were taught through consciousness-raising techniques but the control groups were taught through traditional ways of grammar teaching. After four weeks of instruction, the participants were given post-tests being parallel to the pre-tests. The mean scores comparison and contrast for the pre-tests and the posttests through using Paired T-test revealed a significant improvement in the experimental group's written performance with regard to recognition, proper use and production of the two chosen language items. The findings indicate that cross-linguistic consciousness-raising activities do have a positive effect on the participants' written performance.
\end{abstract}

Keywords: Consciousness-Raising, Cross-Linguistic Comparison, Interlanguage, L1 Referencing

\section{Introduction}

Applying Form-focused instruction (FFI) in L2 pedagogy causes changes in learners' knowledge and use of certain language features (e.g. Day \& Shapson, 1991; Doughty \&Varda, 1998; Harley, 1989). In contrast with meaning focused instruction, FFI "describes instruction where there are some attempts to draw learners' attention to linguistic form" (Ellis, 2001b, p.13). Explicit or implicit teaching, formal instruction and grammar consciousness-raising are the subcategorizations of the FFI. In FFI, there has been a tendency to teach grammar with formal accuracy, and also grammar consciousness-raising has been equated with the explicit teaching of a set of arbitrary rules concerning the linguistic form. Moreover, it would appear that using consciousness-raising as a technique might be a useful means of facilitating the process of second or foreign language learning. Adherents of consciousness-raising $(\mathrm{C}-\mathrm{R})$ believe that for learning a second language, exposure to comprehensive input is necessary, but it does not guarantee successful acquisition (Yip, 1994). To facilitate language learning, they also believe that grammatical consciousness-raising is more effective in developing learner's awareness regarding grammatical structure that mostly occurs at the level of understanding. It would, therefore, appear that more investigation of the use of the consciousness-raising as a technique to teach grammar is needed in confirmation or rejection of the aforementioned assertions.

This study aims to investigate the effects of explicit cross-linguistic consciousness-raising on the written performance of the Iranian English language learners. The focus is on some effects such consciousness-raising might have on the wellformed use of language items, i.e. subject-verb agreement and adverb position in a sentence, and also it is accomplished through determining the frequency of errors and the frequency of well-formed production of these language items in the learners' written performance. The study was conducted to answer the following questions:

1. Do the learners taught based on cross-linguistic C-R technique recognize the written errors better than those in the control groups?

2. Does cross-linguistic C-R technique help participants use subject-verb agreement and adverb position in a sentence in their writing more accurately than those in control groups?

3. Does cross-linguistic C-R technique affect the frequency of written errors learners made in comparison with those in control groups?

Three following hypotheses are made based on the aforementioned research questions: 
1. Cross-linguistic C-R technique helps participants recognize the written errors.

2. Cross-linguistic consciousness-raising encourages ELT learners to use the well-formed language items such as subject-verb agreement and adverb position in a sentence more frequently.

3. Cross-linguistic C-R technique reduces the frequency of written errors learners made

The reason behind choosing these two language items including subject-verb agreement and adverb position in a sentence as the main focus of this study is that in conducting such studies, in order to come to a good or more definite conclusion, justifiable and tangible language items should be selected. Therefore, among numerable areas of concern with regard to common errors for the Iranian language learners, these two language items were selected to be investigated in this study.

\section{Review of the related literature}

In this section the emergence of C-R will be explored in the literature. At first form focused instruction having the major influence on emergence $\mathrm{C}-\mathrm{R}$ is introduced.

\subsection{Form-focused instruction}

Some researchers, considering the shortcomings of the previous approaches to second language teaching and being informed by the findings of empirical studies, support a pedagogical approach which makes benefit of form on the basis of its potential facilitating effect on second language learning (Doughty \& Williams,1998; Harley, 1998; Lightbown, 1991; Long \& Robinson, 1998). The scope of this concept is different in the view of these scholars; Long and Robinson, for example, regard it as an unplanned approach used to draw learners' attention to form. They claim that "Focus on form refers to how focal intentional resources are allocated ...during an otherwise meaning-focused classroom, focus on form often consists of an occasional shift of attention to linguistic code features- by the teacher and/or one or more students- triggered by perceived problems with comprehension or production"(Long \& Robinson 1988: 23). But in Spada's view, it is planning of the language items to be focused on in order to attract the learner's attention. She declares that "form-focused instruction will mean any pedagogical effort which is used to draw the learners' attention to language form either implicitly or explicitly; this can include the direct teaching of grammar language (e.g. through grammatical rules) and/or reactions to learners' errors (e.g. corrective feedback)" (Spada, 1997, p. 73).

Form-focused instruction, which can be found in the title of many works, has born different definitions or interpretations. Ellis $(2001$ b, p. 1) states that FFI "is used to refer to any planned or incidental instructional activity that is intended to induce language learners to pay attention to linguistic form", and similarly Spada (1997, p. 73) interpreted it as "any pedagogical effort which is used to draw the learners' attention to language form either implicitly or explicitly". Thus, consciousness-raising as a subcomponent of FFI appears influential in teaching grammar effectively.

\subsection{Consciousness-raising}

The term consciousness-raising in applied linguistic refers to what Rutherford (1987, p.104) defines as "the drawing of the learner's attention to features of the target language". Consciousness-raising highlights language features for the language learner by developing his or her awareness of them at the moment that the learner is ready to add these features to his or her developing L2 system. It is believed that C-R can help to facilitate the acquisition of grammatical knowledge and it is necessary, though not sufficient, to bring about a successful acquisition (Sugiharto, 2006). Moreover, it is more influential in developing awareness of specific grammatical structures at the level of understanding than to authentic use of them in the real communication. Similarly, Rutherford \& Sharwood-Smith $(1985$, p. 280) states "C-R is considered as a potential facilitator for the acquisition of linguistic competence and has nothing directly to do with the use of that competence for the achievement of specific communicative objectives, or with the achievement of fluency". In practical, both aforementioned applications can be used. In the former, the learner is taught through explicit explanations of grammatical structure. In the latter, the learner is given some sentences and then he/she is then asked to discover or construct the grammar rule for themselves (Sugiharto, 2006). Generally speaking, C-R provides learners with an awareness of linguistic features in the target language. The notion of this awareness in Ellis' (2002) view is (1) being able to consciously "notice" formal properties of the language in the input, and (2) being able to form an explicit representation of a target form, that is the ability to develop explicit knowledge.

Ellis (1990) regards formal instruction as a type of C-R technique to develop learner's awareness of grammatical feature. He suggests that it is through formal instruction that learners become aware of particular features of the target language and form explicit representations of what they are taught. Furthermore, he believes that learners continue to remain aware of the feature and focus their attention in the subsequent communicative input. Willis and Willis (1996) propose teachers to provide learners with consciousness-raising activities, those "activities which encourage them [learners] to think about samples of language and to draw their own conclusions about how the language works" (p. 63). Ellis (1992) believes that C-R is different from practice. He regards practice as being "primarily behavioral" while "consciousness-raising is essentially concept-forming in orientation" (p. 234). Moreover, he asserts that by applying consciousness-raising technique, teachers may attempt "to isolate a specific linguistic feature for focused attention" and language learners are "provided with data which illustrate the target feature", and then learners are "expected to utilize intellectual effort to understand the target feature" (p. 234). He claims, in contrast, by engaging practice, language learners are expected to utter using the target features, and to repeat and perform the features correctly. 


\subsection{Previous studies on $C-R$ approach}

Aidinlou \& Azami (2012) conducted an experimental study in Iran to investigate the role of gender in grammatical consciousness-raising activities. To this end, they chose sixty students from a high school in Babak village, Bilesavar, Ardabil, as the participants of the study. The researchers divided the participants to two groups i.e., experimental and control group. After administrating pre-test, they taught grammar to the experimental group through using C-R activities, but the control group was given communicative activities. Then, they administered a post-test after four weeks of instruction. The results revealed that teaching grammar with C-R activities was useful for the participants and promoted their accuracy.

Lucass (2011) conducted a study in Japan to investigate the effects of such cross-linguistic awareness-raising on the subsequent noticing and frequency of associated errors. The participants were sixty-nine students from two Japanese universities. Two linguistic features i.e., articles and plural suffixes were chosen to be taught during the study. The quantitative results revealed a significant improvement in the identification of articles, as well as in both the identification and production of plurals, but not for the production of articles. Lucass asserted that this latter finding might be accounted for by the fact that articles appear to be a highly complex issue, in addition to certain aspects relating to the validity of the study. The qualitative results generally suggest that the awareness-raising techniques employed are beneficial in helping to improve L2 written accuracy, particularly L1 translation exercises. He concluded that the outcomes of the study provided the language teachers with confidence not to be shy of using the learners' mother tongue. Furthermore, he stated that L1-referencing should certainly not be the sole focus of a syllabus, but judicial and skillful implementation of L1-referencing might enable learners to gain a new set of skills and perspectives that facilitate effective L2 acquisition, particularly with regard to written accuracy.

Runjiang Xu (2011) carried out a study to investigate the effects of C-R on writing ability of the English language learners. The results indicate that C-R influence students' affective state a lot. Runjiang Xu date asserts that previously writing classes seem monotonous to the learners and they consider writing as a heavy load job. He adds language learners, in writing classes, never pay attention to mistakes and repeat the mistakes without the awareness to correct. Moreover, he asserts that this kind of writing does not lead to any improvement in the learners' writing skills but "guide them into a trap of a vicious spiral" (p. 468). After introducing C-R into class, Runjiang Xu asks learners to discover their mistakes by their own or in group work. According to the results, learners, who have experienced success, have positive attitudes towards C-R and also the learners with the lack of success have negative attitudes. Moreover, the learners agree they enjoy writing classes and also the learners declare that they previously show prejudice in English writing.

Moradkhan \& Sohrabian (2009) conducted a study to probe the effects of grammatical consciousness-raising tasks on the improvement of the Iranian students' knowledge of grammar. To this end, from among 100 female intermediatelevel students at a junior high school in Babol, Iran, 60 homogeneous students were assigned to control and experimental groups following the administration of a standardized English proficiency test. Then, a multiple-choice pretest of grammar was administered, the results of which indicated that the two groups were homogeneous in terms of their knowledge of grammar. During the instruction, the experimental group was instructed using grammatical consciousness-raising (C-R) activities to reinforce the grammar points and the control group practiced grammar through the use of communicative techniques. Afterwards, both groups took part in a grammar posttest identical to the one used as the pretest. Using a t-test, the researchers found that the treatment had a significant effect on the grammar knowledge of the experimental group. It was concluded that the use of C-R activities could be a very efficient technique in improving the grammatical knowledge of EFL learners.

Fotos (1993) conducted a study to investigate the amount of learner noticing produced by two types of grammar consciousness raising technique planned to improve formal knowledge of problematic grammar structures: teacherfronted grammar lessons and interactive, grammar problem-solving tasks. After applying grammar consciousnessraising techniques, Foots compared the frequencies of noticing the target structure in communicative input one or two weeks after grammar consciousness-raising treatment with noticing frequencies of the control group which was not exposed to any type of grammar consciousness-raising activity. The results reveal that task performance is as effective as formal instruction in the promotion of subsequent significant amount of noticing. Similarly, many scholars declare that noticing triggers the processing of language learning and they suggest that noticing a feature in input is a critical first step (Rutherford, 1981; Sharwood Smith, 1981). Schmit (1990) offers a distinction between input, and intake by proposing that intake, or noticing linguistic forms, is critical to subsequent processing of the language forms. Furthermore, he asserts that language learners' continuation to notice to the feature in subsequent communicative input facilitates the acquisition of that feature.

\section{Methods}

To conduct this study, an experimental research using control and experimental groups was designed to answer the research questions.

\subsection{Participants}

Sixty intermediate-level learners who were studying at two private language institutes in Yasuj, Iran, were chosen as the participants. They were classified in four groups or classes i.e. two female groups and two male groups. Here, gender was not considered as a variable. Because of gender segregation in the Yasuj language institutes, the participants were chosen from two private institutes. Therefore, four groups, two female and two male, were formed. The subjects were 
classified as two experimental groups, one male and one female group, and two control groups, one male and one female group.

\subsection{Procedures}

Since the participants were chosen from a volunteer population of the intermediate language proficiency learners in the private institutes, they would hopefully be more homogeneous in age and level of language proficiency and to somewhat in experience of learning a foreign language. The participants in the experimental groups were exposed to consciousness-raising activities. The focus was on cross-linguistics comparison of Persian and English. To this end, the instructor explained a language item through comparing and contrasting these items in both languages and also by providing learners with some information which would reveal the usage of these aforementioned language items to help learners distinguish between the L1 and the L2 structures, expecting to prohibit negative transfer from L1 to L2. On the other hand, the control groups were taught through the traditional ways of teaching grammar. They included teacherfronted teaching, the deductive teaching through presenting the rules and giving exercises to practice those rules.

This study "conducted under conditions closer to the normally found in educational context" (Slinger \& Shohamy, 1989, p.149) and it is more likely to have external validity.

\subsection{Instruments}

Three different sets of tests were used to collect the data both as pre-tests and post-tests. The first one was a twenty-item recognition test comprising twenty sentences. Some of these sentences were intentionally erroneous. The participants were required to find those errors. The sentences were mixed and some sentences included more than one grammatical point. Therefore, there was not an identifiable pattern of correct or incorrect sentences. The participants were asked to underline the errors and then to write their correct forms.

The second test used in this phase was the translation test in which participants were required to translate ten sentences from Persian into English sentences. These sentences were chosen in the way that they were appropriate to participants' English language proficiency. The aim of using this test was to reveal participant's knowledge while he/she was translating from Persian into English. Thus, the correct forms of these three grammatical points in the participant's English performance were under consideration. In some translated sentences, two or three of these grammatical points were expected to turn up. Therefore, there was the possibility of having the chance of more than ten times production of these language items.

The third test was a written performance test. It contained two pictures-cued tasks aiming to elicit the participants' production regarding subject-verb agreement and adverb position in a sentence. The participants were required to write a paragraph to describe each picture. Moreover, they were required to answer some questions relating to each picture. They were also asked to write what had come to their mind about the picture without any need for immediate correction.

As one of the primary aims of this study, in order to investigate the effects of direct instruction on the participants' outcome or learning, three sets of post-tests, parallel to the pretests, were administered. They were designed in harmony with pre-tests, so the number of tasks, items and sentences were exactly the same as those in the pre-tests.

\subsection{Data collection}

In order to collect the data, at first, three tests were administered as the study pre-tests to elicit the participants' production of these understudied language items. The learners' outcomes of these tests were used as the base materials to be explicitly taught by referring to production of these aforementioned language items in L1 in comparison with those in L2. Then, the language items were explicitly taught during four weeks. In the fourth week, the previous taught materials were reviewed. Finally, the post-tests were administered. These post-tests, like the pre-test, included error recognition test, translation test and writing production test.

This process was the same for both experimental and control groups but the only difference was that there were no cross-linguistic consciousness-raising activities in control groups' teaching package. At last, the data were collected and were ready for the analysis.

\subsection{Data analysis}

After administering both pre-tests and post-tests, the participants' performance on these tests was scored and organized. The collected data were submitted to SPSS software through which outcomes of the pre-tests were compared to those of the post-tests by applying the paired T-Test in the SPSS software. Finally, the results of experimental groups were compared to those of the control groups in the same way.

\section{Results}

The results are organized and presented with respect to the research questions. First of all, in order to respond to the first research question, stating "do the learners taught based on cross-linguistic $C$ - $R$ technique recognize the written errors", the participants' performance over the error recognition tests is displayed in the following sections.

\section{Subject-verb agreement}

The participants' performance over the recognition tests regarding the identification of subject-verb agreement is given in table 1. 
Table 1. T-Test Results for Comparing the Participant's Performance on Pre-Test and Post Test Regarding

Recognition of Incorrect Use of Subject-Verb Agreement

\begin{tabular}{|c|c|c|c|c|c|c|c|c|}
\hline \multirow{3}{*}{ group } & \multicolumn{5}{|c|}{ Paired Differences } & \multirow[b]{3}{*}{$\mathrm{T}$} & \multirow[b]{3}{*}{ df } & \multirow[b]{3}{*}{$\begin{array}{l}\text { Sig. } \\
\text { (2-tailed) }\end{array}$} \\
\hline & \multirow[b]{2}{*}{ Mean } & \multirow[b]{2}{*}{$\begin{array}{l}\text { Std. } \\
\text { Deviation }\end{array}$} & \multirow[b]{2}{*}{$\begin{array}{l}\text { Std. Error } \\
\text { Mean }\end{array}$} & \multicolumn{2}{|c|}{$\begin{array}{l}95 \% \text { Confidence } \\
\text { Interval of the Difference }\end{array}$} & & & \\
\hline & & & & Lower & Upper & & & \\
\hline $\begin{array}{l}\text { Control group } \\
\text { Pair } 1 \text { pre-test__post-test }\end{array}$ & -1.286 & 1.213 & .229 & -1.756 & -.815 & -5.610 & 27 & .000 \\
\hline $\begin{array}{l}\text { Experimental group } \\
\text { Pair } 2 \text { pre-test_post-test }\end{array}$ & -2.643 & 1.026 & .194 & -3.041 & -2.245 & -13.629 & 27 & .000 \\
\hline
\end{tabular}

Table1 shows that, for the experimental group's performance over the pre-test and the post, the obtained value for $p$ with 27 degrees of freedom at the 0.05 level of significance is .000 . Since this value is smaller than $0.05(\mathrm{P}=0.00<$ 0.05), it can be concluded that there is a significant difference between the experimental group's performance on the pre-test and the post-test, so the difference is not related to the chance. This difference is markedly in favor of the experimental group. Thus, it reveals that the participants in the experimental group have a great improvement in recognizing the errors.

The results for the experimental and the control groups reveal the positive impact of consciousness-raising activities on the participant's recognition of the subject-verb agreement. In other words, the experimental group benefiting from the consciousness-raising activities had a better improvement in comparison with the control group which benefited from traditional ways of grammar teaching. Figure 1 shows this comparison.
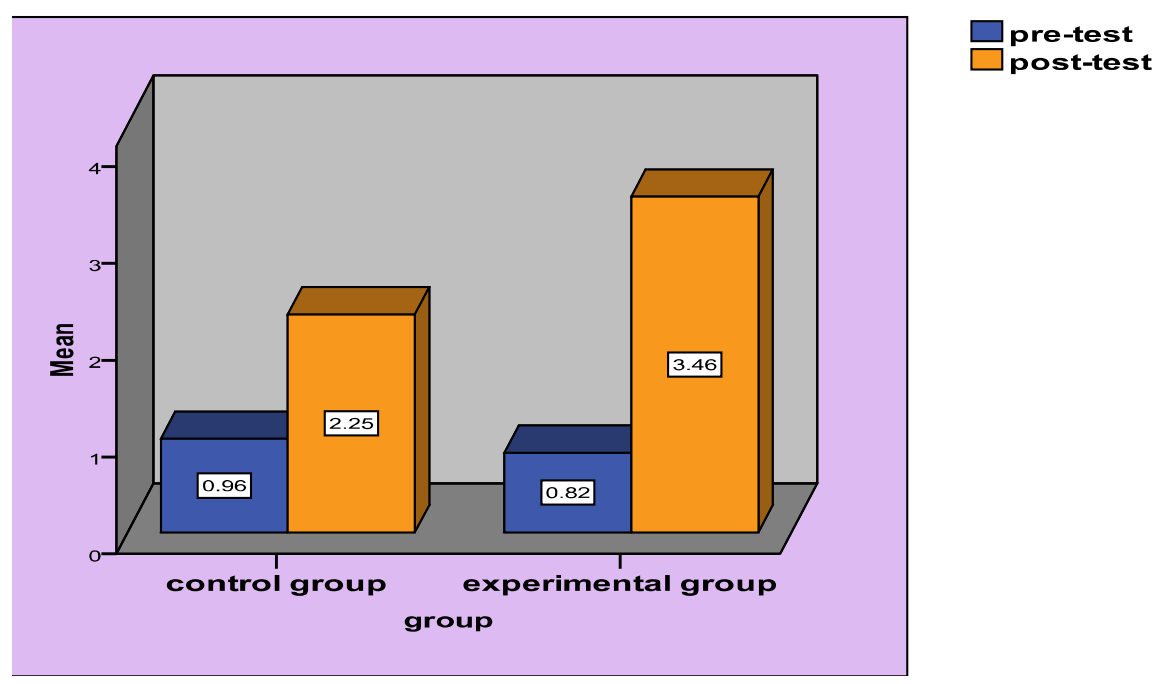

Figure 1. Mean score of the recognition of the incorrect use of subject-verb agreement between the control and experimental groups

Adverb position in a sentence

The participants' performance over the recognition tests regarding the identification of adverb position in a sentence is given in table

Table 2. T-Test Results for Comparing the Participant's Performance on Pre-Test and Post Test Regarding Recognition of Incorrect Use of Adverb Position in a Sentence

\begin{tabular}{|c|c|c|c|c|c|c|c|c|}
\hline \multirow{3}{*}{ group } & \multicolumn{5}{|c|}{ Paired Differences } & \multirow[b]{3}{*}{$\mathrm{T}$} & \multirow[b]{3}{*}{ df } & \multirow[b]{3}{*}{$\begin{array}{l}\text { Sig. } \\
\text { (2-tailed) }\end{array}$} \\
\hline & \multirow[b]{2}{*}{ Mean } & \multirow[b]{2}{*}{$\begin{array}{l}\text { Std. } \\
\text { Deviation }\end{array}$} & \multirow[b]{2}{*}{$\begin{array}{l}\text { Std. Error } \\
\text { Mean }\end{array}$} & \multicolumn{2}{|c|}{$\begin{array}{l}95 \% \text { Confidence } \\
\text { Interval of the Difference }\end{array}$} & & & \\
\hline & & & & Lower & Upper & & & \\
\hline $\begin{array}{l}\text { Control group } \\
\text { Pair } 1 \text { pre-test__ post-test }\end{array}$ & -.857 & 1.213 & .223 & -1.314 & -.401 & -3.852 & 27 & .001 \\
\hline $\begin{array}{l}\text { Experimental group } \\
\text { Pair } 2 \text { pre-test__post-test }\end{array}$ & -2.429 & 1.026 & .274 & -2.991 & -1.866 & -8.856 & 27 & .000 \\
\hline
\end{tabular}


Table 2 displays that, for the experimental group's performance over the pre-test and the post, the obtained value for $p$ with 27 degrees of freedom at the 0.05 level of significance is .000 . Since this value is smaller than $0.05(\mathrm{P}=0.00<$ 0.05), it can be concluded that there is a significant difference between the experimental group's performance on the pre-test and the post-test, so the difference is not related to the chance. These data display that the mean score difference between the pre-test and the post-test is in favor of the experimental group. In other words, the difference between the experimental groups' performance over the pre-test and the post-test of error recognition with regards to identification of adverb position in a sentence is considerable. It means that the participants in the experimental group have a great improvement in recognizing errors.

The results for the experimental and the control group reveal a positive effect of consciousness-raising activities on the participant's recognition of the adverb position in a sentence. It is evident that the mean score difference between the pre-test and the post-test is in favor of experimental group. In other words, the experimental group benefiting from the consciousness-raising activities had a better improvement in comparison with the control group which did not benefit from the consciousness-raising activities. Figure 2 illustrates this comparison.
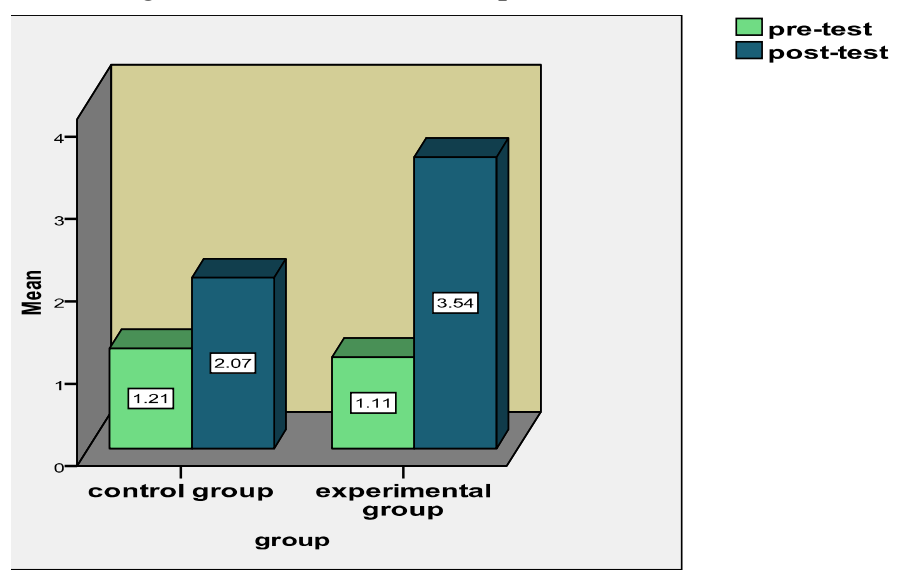

Figure 2. Mean Score of the Recognition of the Incorrect Use of Subject-Verb Agreement between the Control and Experimental Groups

The second research question asks "does cross-linguistic C-R technique help participants use subject-verb agreement and adverb position in a sentence in their writing more accurately than those in control groups?" In order to respond to this question, the participants' performance over the translation tests are presented.

Subject-verb agreement

The participants' performance over the translation tests regarding subject-verb agreement is represented in table 3.

Table 3. T-Test Results for Comparing the Participant's Performance over Pre-Test and Post Test Regarding Subject Verb Agreement in the Translation Tests

\begin{tabular}{|c|c|c|c|c|c|c|c|c|}
\hline \multirow{3}{*}{ Group } & \multicolumn{5}{|c|}{ Paired Differences } & \multirow[b]{3}{*}{$\mathrm{T}$} & \multirow[b]{3}{*}{ df } & \multirow[b]{3}{*}{$\begin{array}{l}\text { Sig. } \\
\text { (2-tailed) }\end{array}$} \\
\hline & & & & \multicolumn{2}{|c|}{$\begin{array}{l}95 \% \text { Confidence } \\
\text { Interval of the Difference }\end{array}$} & & & \\
\hline & Mean & $\begin{array}{l}\text { Std. } \\
\text { Deviation }\end{array}$ & $\begin{array}{l}\text { Std. Error } \\
\text { Mean }\end{array}$ & Lower & Upper & & & \\
\hline $\begin{array}{l}\text { Control group } \\
\text { Pair } 1 \text { pre-test__ post-test }\end{array}$ & -.500 & .962 & .182 & -.873 & -.127 & -2.750 & 27 & .011 \\
\hline $\begin{array}{l}\text { Experimentalgroup } \\
\text { Pair } 2 \text { pre-test_post-test }\end{array}$ & -1.179 & .723 & .137 & -1.459 & -.898 & -8.628 & 27 & .000 \\
\hline
\end{tabular}

Table 3 reveals that, for the experimental group's performance over the pre-test and the post, the obtained value for $\mathrm{p}$ with 27 degrees of freedom at the 0.05 level of significance is .000 . Since this value is smaller than $0.05(P=0.00<$ $0.05)$, it can be concluded that there is a significant difference between the experimental group's performance on the pre-test and the post-test. The data display that the mean score difference between the pre-test and the post-test is in favor of the experimental group. In other words, the difference between the experimental groups' performance over the pre-test and the post-test of translation tests with regards to subject-verb agreement is considerable. It means that the participants in the experimental group have a great improvement.

The results for the experimental and the control group revealed the positive impact of consciousness-raising activities on the participant's performance. Consequently, the experimental group benefiting from the consciousness-raising 
activities had a better improvement in comparison with the control group which did not benefit from the consciousnessraising activities. Figure 3 shows this comparison.
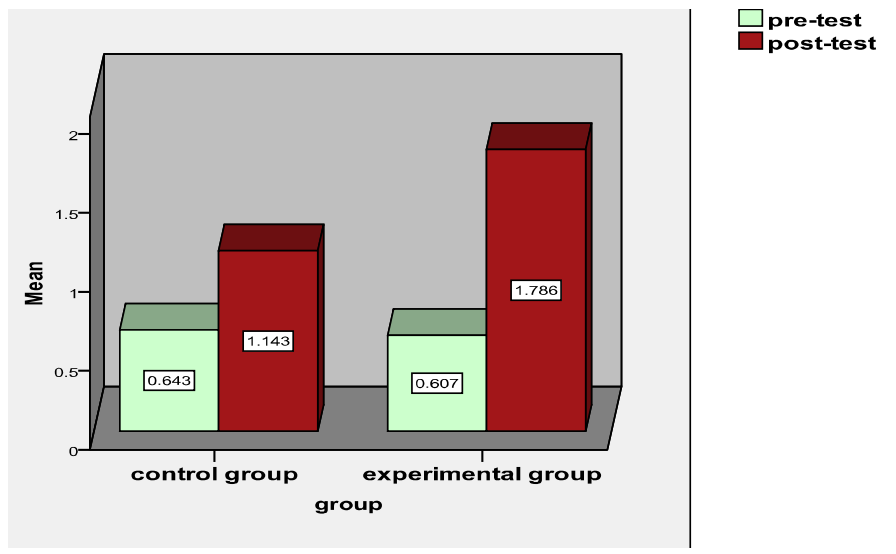

Figure 3. Mean Score of the Participant' Performance over Subject Verb Agreement between the Control and Experimental Groups

Adverb position in a sentence

Table 4 presents the participants' performance over the translation tests regarding adverb position in a sentence.

Table 4. T-Test Results for Comparing the Participant's Performance over Pre-Test and Post Test Regarding Adverb Position in a Sentence

\begin{tabular}{|c|c|c|c|c|c|c|c|c|}
\hline \multirow{3}{*}{ Group } & \multicolumn{5}{|c|}{ Paired Differences } & \multirow[b]{3}{*}{$\mathrm{T}$} & \multirow[b]{3}{*}{ df } & \multirow[b]{3}{*}{$\begin{array}{l}\text { Sig. } \\
\text { (2-tailed) }\end{array}$} \\
\hline & & & & \multicolumn{2}{|c|}{$\begin{array}{l}95 \% \text { Confidence } \\
\text { Interval of the Difference }\end{array}$} & & & \\
\hline & Mean & $\begin{array}{l}\text { Std. } \\
\text { Deviation }\end{array}$ & $\begin{array}{l}\text { Std. Error } \\
\text { Mean }\end{array}$ & Lower & Upper & & & \\
\hline $\begin{array}{l}\text { Control group } \\
\text { Pair } 1 \text { pre-test__ post-test }\end{array}$ & -1.107 & 1.397 & .264 & -1.649 & -.566 & -4.194 & 27 & .000 \\
\hline $\begin{array}{l}\text { Experimental group } \\
\text { Pair } 2 \text { pre-test_post-test }\end{array}$ & -2.179 & 1.278 & .242 & -2.674 & -1.683 & -9.019 & 27 & .000 \\
\hline
\end{tabular}

Table 4 shows that, for the experimental group's performance over the pre-test and the post, the obtained value for $\mathrm{p}$ with 27 degrees of freedom at the 0.05 level of significance is .000 . Since this value is smaller than $0.05(\mathrm{P}=0.00<$ $0.05)$, it can be concluded that there is a significant difference between the experimental group's performance on the pre-test and the post-test. As it is obvious from these data, the mean score difference between the pre-test and the posttest is in favor of the experimental group. In other words, the difference between the experimental groups' performance over the pre-test and the post-test of writing production with regards to articles is considerable. It means that the participants in the experimental group have a great improvement.

The results for the experimental and the control group by considering these data together with the data presented in the table 4 reveal a positive effect of consciousness-raising activities on the participant's performance. In other words, the experimental group benefiting from the consciousness-raising activities had a better improvement in comparison with the control group which benefited from the traditional ways of grammar teaching. Figure 4 shows this comparison.

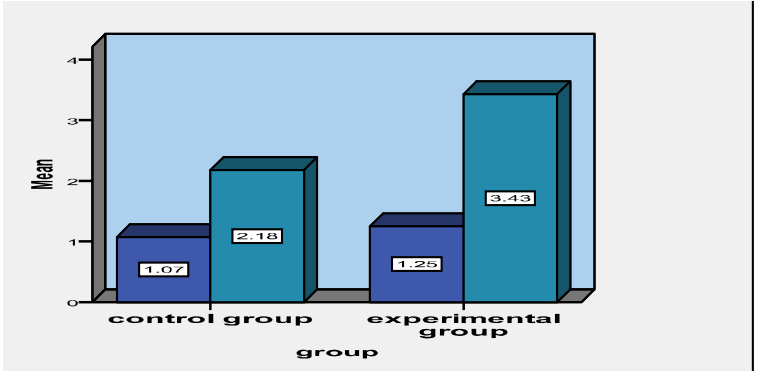

pro-tost

Figure 4. Mean Score of the Participant' Performance over Adverb Position in a Sentence between the Control and Experimental Groups 
To answer to the third research question, stating "does cross-linguistic C-R technique affect the frequency of written errors learners made in comparison with those in control groups?", the following results that are the participants' performance over the writing tests are presented.

\section{Adverb position in a sentence}

The participants' performance over the writing tests regarding adverb position in a sentence is represented in table 5 .

Table 5. T-Test Results for Comparing the Participant's Performance over Pre-Test and Post Test Regarding Adverb Position in a Sentence

\begin{tabular}{|c|c|c|c|c|c|c|c|c|}
\hline \multirow{3}{*}{ Group } & \multicolumn{5}{|c|}{ Paired Differences } & \multirow[b]{3}{*}{$\mathrm{T}$} & \multirow[b]{3}{*}{ df } & \multirow[b]{3}{*}{$\begin{array}{l}\text { Sig. } \\
\text { (2-tailed) }\end{array}$} \\
\hline & & & & \multicolumn{2}{|c|}{$\begin{array}{l}95 \% \text { Confidence } \\
\text { Interval of the } \\
\text { Difference }\end{array}$} & & & \\
\hline & Mean & Deviation & $\begin{array}{l}\text { Std. Error } \\
\text { Mean }\end{array}$ & Lower & Upper & & & \\
\hline $\begin{array}{l}\text { Control group } \\
\text { Pair } 1 \quad \text { pre-test __ post- } \\
\text { test }\end{array}$ & -23.571 & 20.716 & 3.915 & -31.604 & -15.539 & -6.021 & 27 & .000 \\
\hline $\begin{array}{l}\text { Experimental group } \\
\text { Pair } 2 \text { pre-test_post- } \\
\text { test }\end{array}$ & -38.464 & 24.915 & 4.709 & -48.125 & -28.803 & -8.169 & 27 & .000 \\
\hline
\end{tabular}

Table 5 reveals that, for the experimental group's performance over the pre-test and the post, the obtained value for $\mathrm{p}$ with 27 degrees of freedom at the 0.05 level of significance is .000 . Since this value is smaller than $0.05(P=0.00<$ 0.05 ), it can be concluded that there is a significant difference between the experimental group's performance on the pre-test and the post-test. These data display that the mean score difference between the pre-test and the post-test is in favor of the experimental group. In other words, the difference between the experimental groups' performance over the pre-test and the post-test of writing production with regards to adverb position in a sentence is considerable. It means that the participants in the experimental group have a great improvement.

The results for the experimental and the control group reveal the impact of consciousness-raising activities on the participant's performance regarding adverb position in a sentence. In other words, the experimental group benefiting from the consciousness-raising activities had a better improvement in comparison with the control group which did not benefit from the consciousness-raising activities. This comparison reveals to what extent the experimental group benefiting from L1 referencing have improved. Figure 4.8 displays this comparison.
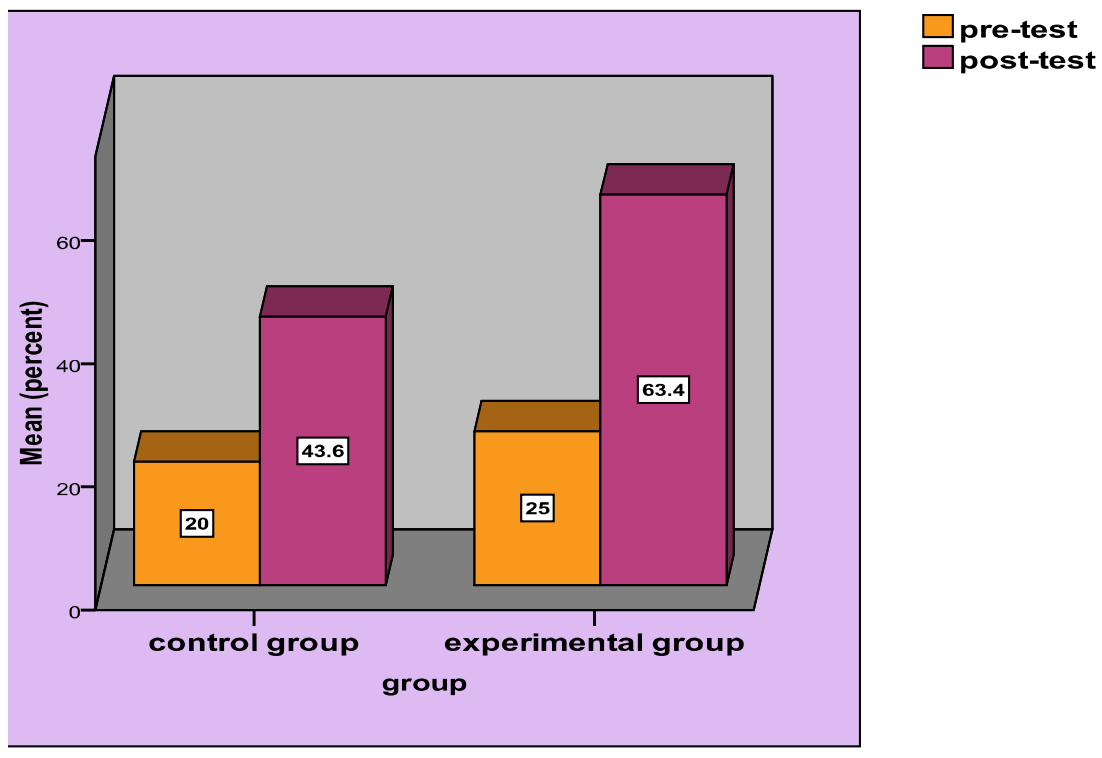

Figure 5. Mean Score of the Participant' Performance over the Writing Tests Regarding Adverb Position in a

Sentence between the Control and Experimental Groups 


\section{Discussion}

The results of the study showed that consciousness-raising activities helped the learners do better in recognizing those errors related to adverb position in a sentence. As the data revealed, a great improvement in the production of the experimental group occurred in comparison with the production of the control group. While comparing the learners' performance over the two tests, i.e., subject-verb agreement and adverb position in a sentence, one can see a consistent improvement in the experimental group's production. This consistency in the learners' production with regard to their performance over the three aforementioned tests proves the first research hypothesis stating cross-linguistic C-R technique helps participants recognize the written errors.

The findings of the current study go well together with the study carried out by Lucass (2011), in which he has illustrated that judicial and skillful implementation of awareness-raising activities might enable learners to gain a new set of skills and perspectives that facilitate effective L2 learning, particularly with regard to written accuracy. Lucass' study has revealed a significant improvement in the identification of articles by the participants' benefitting from awareness-raising techniques, as well as in both the identification and production of plurals, but not for the production of the articles. The findings of the current study do not confirm the latter one because it was found that there was an outstanding improvement in the participants' production of the articles. Lucass has asserted that this latter finding might be accounted for by the fact that articles appear to be a highly complex issue, in addition to certain aspects relating to the validity of his study.

In addition, another study conducted by Jinlin \& Baimei (2011) indicates that the C-R activities improve the use of the students' reference material and their ability to notice gaps in meaning, increase their interest and confidence in learning English, and guide their personal learning of vocabulary. The results of the current study also confirm the findings of Aidinlou \& Azami's (2012) study, an experimental study conducted in Iran to investigate the role of gender in grammatical consciousness-raising activities. It reveals that teaching grammar with $\mathrm{C}-\mathrm{R}$ activities is useful for the participants and promotes their accuracy.

As the results show, for the second research question, there is a markedly improvement in the experimental group's performance over the two aforementioned language items. Furthermore, there is a consistency in the obtained results regarding error recognition of the two language items. Therefore, it can be concluded that these consistent results prove the first research hypothesis, stating that Cross-linguistic C-R technique helps participants recognize the written errors. Moreover, it deserves mentioning that the most of the above-mentioned studies confirm this hypothesis. Consequently, for those who are involved in the process of language teaching and learning, this study may provide rich findings to rely on. Whereby findings of this study pave the way for other researchers in the domain of SLA with the focus of teaching grammar

Furthermore, it was found that consciousness-raising activities helped the learners do better in the correct use of subject verb agreement and in the correct use of adverb position in a sentence. These results confirm the findings of Moradkhan \& Sohrabiani's (2009) study carried out to probe the effects of grammatical consciousness-raising tasks on the improvement of the Iranian students' knowledge of grammar. They conclude that the use of C-R activities could be a very efficient technique in improving the grammatical knowledge of EFL learners.

The findings of this research also mirror Amirian \& Sadeghi's (2012) study established to investigate different approaches in grammar teaching and to compare the traditional approaches with Consciousness-Raising tasks. They apply some C-R tasks in the EFL classroom for one session per week and probed the effectiveness of these tasks. Their results indicate that using CR tasks in grammar teaching is significantly more effective than the traditional approaches.

The results obtained from the translation tests reveal a consistent improvement in the experimental group's performance regarding the proper use of the three aforementioned language items. The consistency of these results together with the findings revealed in the literature mentioned in this study, most of which confirm the current study findings, provide a rich data to answer the second research question, whereby proving the research hypothesis stating Cross-linguistic consciousness-raising encourages ELT learners to use the well-formed language items such as Subject-Verb agreement, Adverb position in a sentence and Articles more frequently. Consequently, these findings enrich this assertion stating the cross-linguistic C-R technique, in other words the L1 referencing in teaching L2, facilitates the process of a second or foreign language. Therefore, as a an effective technique to teach grammar, cross-linguistic C-R would provide the language teachers with time consuming and successful activities to accelerating the language learners' learning process.

All in all, they reveal the positive effect of cross-linguistic C-R activities. These results confirm the findings of Crivos \& Luchini's (2012) study carried out to answer the question of which concept of grammar should be considered more appropriate in ELT mainstream. To answer this question, they analyze two different ways of teaching grammar in the EFL classroom: traditional grammar practice and consciousness-raising. They highlight some areas of convergence and divergence between these two approaches and also they present some examples of consciousness-raising tasks for the teaching of grammar. They assert that effective grammar teaching model should aim to help students become aware of how grammatical features operated. This awareness, they declare, could facilitate and trigger learning and help students in the process of becoming active participants and less dependent on teachers.

The findings of this study contradict Fotos and Ellis's (1991) study conducted in Japan to compare the effectiveness of consciousness raising tasks with traditional teacher-fronted grammar lessons. Fotos and Ellis conclude that "the task appeared to have functioned equally well as the grammar lesson in the short term, and is only slightly less effective in 
maintaining proficiency than the grammar lesson after 2 weeks" (p. 619). However, in contrast, the findings of the current study indicate that C-R activities are more effective in maintaining learners' proficiency than traditional teacher fronted grammar lessons.

Like the two above-mentioned research questions, the third one is answered by the results which reveal a markedly improvement in the experimental group's performance. Whereby, they provide rich data based on the third research hypothesis stating Cross-linguistic C-R technique reduces the frequency of written errors learners made. Putting the findings related to three aforementioned research questions together with the literature finding mentioned above, most of them confirm the current study findings, one can concluded that cross-linguistic C-R as a technique to teach grammar deserves paying attention. An interesting point revealed in this study is the consistency of the experimental group's improvement over eight pair tests. The results of the T-test for the eight pair tests revealed such a consistency without any exception. In addition, these results confirm most of the afore-mentioned literatures findings. This study supports the usefulness of C-R activities in teaching grammar to EFL learners. The results also revealed that applying C-R activities can facilitate learning grammar.

As one of the advantages of the cross-linguistic comparison, it can help language learners to compare their new finding with their current interlanguage and by so doing notice the gap between their understanding of the use and usage of a language item, and the way it is used by native speakers. In this regard, the learners revise their interlanguage towards more a native-like form and eventually towards acquisition of that form.

Another advantage of cross-linguistic $\mathrm{C}-\mathrm{R}$ is that it provides language learners awareness sensitizing them to the structure of target language in a way that it is different from the learners' first language. Applying C-R activities enables language learners to circumscribe the negative transfer from their first language. In teaching language, the combination of explicit and implicit knowledge of first language and also target language can guide learners toward language learning.

The main outcome of the present study is that the use of C-R activities in the classroom is a suitable technique in teaching grammar to the language learners. It seems that it is better for the teacher to be aware of different techniques in teaching grammar and use them while teaching grammar. Moreover, C-R techniques create the awareness and sense of language because the learners involve in the process of learning by using activities and tasks which make inner correction if they have mistakes. C-R activities encourage learners to think about samples of language and draw their own conclusion about how the language works. Consequently, consciousness is crucial for learning, and no learning can take place without attention and some levels of awareness. Learning without consciousness is so limited that its effects are negligible.

\section{Conclusion}

This study was carried out to investigate the effects of explicit cross-linguistic consciousness-raising (CR) on the EL written performance. To meet this end, two language items, subject-verb agreement, adverb position in a sentence chosen to be probed.

Consciousness-raising is considered by us as a process of potential facilitator for the learning of linguistic competence. As such, $\mathrm{C}-\mathrm{R}$ is to be seen as one part of a large pedagogical context that encompasses as well the other prerequisites for the target language mastery. It was necessary to recognize that consciousness-raising is a general pedagogical technique which can be practical very broadly to different areas of language teaching.

\section{References}

Aidinlou, N. A. \& Azami, J. (2012). An investigation of the role of gender in grammatical consciousness-raising activities. Journal of Basic and Applied Scientific Research, 2(4), 3349-3353

Amirian M. S. \& Sadeghi F. (2012). The effect of grammar consciousness-raising tasks on EFL learners performance. International Journal of Linguistics, 4 (3), 64-95.

Crivos, M. B., \& Luchini, P. L. (2012). A pedagogical proposal for teaching grammar using consciousness-raising tasks. MJAL 4(3), 141-153.

Day, E. M. and Shapson, S. M. (1991). Integrating formal and functional approaches to language teaching in French immersion: An experimental study. Language Learning 41, 25-58.

Doughty, C. and Williams, J. (1998). Pedagogical choices in focus on form. In Doughty, C. and

Duffy , M.E. (1987). Methodological triangulation a vehicle for merging quantitative and qualitative methods. Image, 19(3), 130-133.

Ellis, N. (2002). Frequency effects in language processing: a review with implications for theories of implicit and explicit language acquisition. Studies in Second Language Acquisition 24: 123-146.

Ellis, R. (2001). Investigating form-focused instruction. Language Learning, 51, 281-318.

Ellis, R. (1997). Second language acquisition. Oxford: Oxford University Press.

Fotos, S. (1993). Consciousness raising and noticing through focus on form: Grammar task performance versus formal instruction. Applied Linguistics 14(4), 385-407. 
Fotos,S. and Ellis R. (1991). Communicating about grammar: Atask-based pproach. TESOL Quarterly 25(4), 605-628.

Jilin, J. \& Baimei, S. (2011). An application of consciousness-raising activities when teaching vocabulary to English majors. Journal of Applied Linguistics (Quarterly) 34 (2).

Harley, B. (1989). Functional grammar in French immersion: A classroom experiment. Applied Linguistics 10, 331359.

Lightbown, P.M. (1991). What have we here? Some observations on the influence of instruction on L2 learning. In: Phillipson, R., Kellerman, E., Selinker, L., Sharwood Smith, M., Swan, M. (Eds.), Foreign/Second Language Pedagogy Research. Multilingual Matters 64, Clevedon.

Long, M.H. and Robinson, P. (1998). Focus on form: Theory, research, and practice. In Doughty, C. and Williams, J., Focus on form in classroom second language acquisition. Cambridge: Cambridge University Press.

Lucas M. W. (2011). Crossing the frontier: An investigation into the effects of explicit cross-linguistic awarenessraising on the subsequent L2 written performance of Japanese learners, unpublished MA thesis, The Westminster Institute of Education at Oxford Brookes University.

Moradkhan, D. \& Sohrabian, R. (2009). Grammatical consciousness-raising tasks and the improvement of Iranian students' Knowledge of grammar, Journal of Teaching English as a Foreign Language and Literature, 1(4), 57-71.

Rutherford W.E. (1987). Second language grammar: Teaching and learning. Harlow: Pearson Education Limited.

Rutherford, W. \& Smith, M. (1988). Grammar and Second Language Teaching. New York: Newbury House.

Seliger, H. W. \& Shohamy, E. G. (1989). Second language research methods. Oxford University Press.

Sharwood Smith, M. (1981). On interpreting language input. Paper presented at the BAAL Seminar on interrative strategies in language learning University of Lancaster

Schmidt, R.W. (1990). The role of consciousness in second language learning. Applied Linguistics, 11(2), 129-158.

Spada, N. (1997). Form-focussed instruction and second language acquisition: A review of classroom and laboratory research. Language Teaching, 30, 73-87.

Sugiharto, S. (2006).Grammar Consciousness-Raising: Research, Theory, and Application.

Indonesian Journal of English Language Teaching, 2, 140-148.

Willis, J. and Willis, D. (1996). Consciousness-raising Activities. In Willis, J. and Willis, D. (eds.) (1996): 64

$\mathrm{Xu}, \mathrm{R}$., \& Pan, Q. (2011). A study of college English writing classes through consciousness-raising. Journal of Language Teaching and Research, 2(2), 467-470.

Yip, V. (1994). Grammatical consciousness-raising and learnability. In Odlin, T. (ed.) Perspectives on Pedagogical Grammar. Cambridge: Cambridge University Press. 